\title{
Leitura e Escrita no Curso Secundário: Do Ensino de Preceitos Retórico-Poéticos ao Jncentivo à Originalidade e Criatividade (IgI4-Ig6g)
}

Rejane Rodrigues Almeida de MEDEIROS*

* Doutora em Linguística pela Universidade Federal de São Carlos (2019), é professora de Português na rede pública e privada de ensino.E-mail: rejane_almeidademedeiros@yahoo.com.br

\begin{abstract}
Resumo:
No ensino da escrita nas aulas de português do curso secundário podem ter havido, primeiramente, práticas que mobilizavam conhecimentos retórico-poéticos mesclados à ideia de originalidade, até aproximadamente a primeira metade do século XX. Posteriormente, nas décadas de 1950 e 1960, quando a noção de originalidade é aprofundada, tais práticas passaram a valorizar a criatividade individual do aluno na elaboração da escrita. O objetivo deste artigo é discutir o modo como preceitos retórico-poéticos, assim como os conceitos de originalidade e criatividade apresentam-se em orientações para o ensino da escrita de textos didáticos publicados entre 1914 e 1969. A análise da antologia escolar Céu, terra e mar (1914), de Alberto de Oliveira, do manual do professor O idioma nacional na escola secundária (1935), de Antenor Nascentes, da coleção didática para o ginásio Português através de textos (1960-1969), de Magda Soares, e do artigo "Importância da composição" (1951), veiculado na Revista de Educaşão, que compõem o nosso corpus, é subsidiada pelo referencial teórico-metodológico da História Cultural da Leitura. Em livros escolares editados entre 1914 e 1935, são recomendados preceitos retórico-poéticos, como os de invenção, disposição e elocução, que compreendem as três operações retóricas para a composição de discursos, além do de imitação, ao mesmo tempo em que a originalidade na escrita é também incentivada. Nos anos de 1960, o incentivo à escrita original faz então surgir a ideia de escrita como atividade criativa individual em novos livros escolares e em artigos de revistas de ensino elaborados no período.
\end{abstract}

\section{Palavras-chave:}

Ensino da escrita; ensino da leitura; história do ensino de português. 


\section{Leitura e Escrita no Curso Secundário: Do Ensino de Preceitos Retórico-Poéticos ao Incentivo à Originalidade e Criatividade (1914-1969)}

Rejane Rodrigues Almeida de Medeiros

\section{INTRODUÇÃO}

A retórica e a poética exerceram uma influência significativa sobre o ensino de português ministrado na escola secundária durante a segunda metade do século XIX e as primeiras décadas do XX. Depois de ter sido institucionalizada primeiramente como estudos de gramática no Colégio Pedro II, em 1838, a disciplina escolar Português incluiu posteriormente em seu programa, a partir da década de 1850, a leitura e a recitação de textos, práticas antes restritas às cadeiras de Retórica e Poética (RAZZINI, 2000 , p. 42). Vinte anos mais tarde, a partir de 1870, os planos de estudos de português passaram a abarcar também exercícios de redação em suas orientações, os quais deveriam ser realizados após a leitura de trecho de algum clássico, seguida de sua explicação pelo professor. A leitura de um texto literário modelar, como preparação aos exercícios de redação, pode ter sido preponderante nas práticas de ensino da escrita até a década de 1960, conforme sugerem as indicações de livros escolares editados à época e programas de ensino de português vigentes no mesmo período.

Apesar da extinção da Retórica e Poética do currículo do secundário, alguns preceitos dessas disciplinas, como os de invenção, disposição e elocução, que compreendem as três operações retóricas para a composição de discursos, assim como o de imitação, são utilizados em textos didáticos publicados entre 1914 e 1935. Ao proceder à escrita de um texto, os alunos deveriam colocar em prática tais preceitos, depois de terem observado a sua aplicação em um texto literário previamente lido, que lhes servia de exemplo. Por outro lado, nesses mesmos textos didáticos, incentiva-se também a originalidade. Esse paulatino incentivo à escrita original faz então surgir a ideia de escrita como atividade criativa individual em novos livros escolares elaborados a partir de 1960 e em artigos de revistas de ensino. O objetivo deste artigo é discutir o modo como preceitos retórico-poéticos são apropriados e mesclados ao conceito de originalidade na antologia escolar Céu, terra e mar (1914), de Alberto de Oliveira, e no manual do professor O idioma nacional na escola secundária (1935), de Antenor Nascentes; assim como a ideia de redação como criatividade motivada pela leitura é tratada na coleção didática para o ginásio Português através de textos (19601969), de Magda Soares, e no artigo "Importância da composição" (1951), publicado na Revista de Educação. A antologia escolar Céu, terra e mar foi publicada em 1914, pela Livraria Francisco Alves, a qual havia sido criada em 1897, tornando-se a principal editora no segmento de livros didáticos no Brasil (cf. HALLEWELL, 2005, p. 280). Organizada pelo professor e poeta parnasiano Antonio Mariano Alberto de Oliveira, o livro era composto por textos em verso e em prosa, e segundo Pfromm Netto et all. (1974, p. 203), apresentava a "curiosidade de agrupar os trechos selecionados por ordem de assunto (manhãs, meios-dias, tardes, noites, estrelas, montanhas, o mar, árvores, flores, rios, florestas, etc.)". A importância que essa antologia adquiriu no espaço escolar pode ser ainda atestada por sua presença nas memórias do eminente educador Paschoal Lemme (1904-1997), que registra o papel dos textos reunidos em Céu, terra 
e mar na leitura em voz alta, principalmente na recitação de poesias, realizada nas aulas de língua materna (LEMME, 2004, v. I, p. 89-91).

O idioma nacional na escola secundária, de Antenor Nascentes, fez parte da Biblioteca de Educação da Companhia Melhoramentos de São Paulo, um projeto assentado no ideário escolanovista, dirigido por Lourenço Filho. Com o intuito de oferecer um saber especializado ao professor de português que, devido à inexistência de Faculdades de Letras no período, era um autodidata em língua e literatura, formado, muitas vezes, nas Faculdades de Direito -, o manual surge em 1935, com explicações sobre conteúdos e métodos de ensino de português para as cinco primeiras séries do curso secundário.

A coleção didática Português através de textos, de Magda Soares, foi publicada entre os anos de 1960 e 1969 pela Editora Bernardo Álvares, de Belo Horizonte. A obra, que apresentava o aspecto inovador de integrar estudo de texto e estudo gramatical, era composta por quatro livros do aluno, sendo um para cada série do ginásio, além de um manual do professor, o qual tinha sido concebido como auxiliar ao trabalho do professor de português.

A Revista de Educação, da qual se extrai o artigo "Importância da composição" (1951), foi uma publicação periódica da Diretoria Geral da Instrução Pública de São Paulo em conjunto com a Sociedade de Educação (uma associação de professores primários do estado), que, mais tarde, ficou a cargo apenas da Secretaria da Educação de São Paulo. Apresentou um longo ciclo de vida, que durou de 1927 a 1961, com algumas interrupções (cf. CATANI, 1996, p. 125). De acordo com o Catálogo da Imprensa Periódica Educacional Paulista (1890-1996), organizado por Catani e Sousa (1999, p. 84), o impresso surge com o nome Educação em 1927, continua como Escola Nova entre 1930 e 1931, retorna ao título original entre os anos de 1931 e 1932, e é editada como Revista de Educação entre 1933 e 1943 e de 1951 a 1961. Sua periodicidade também é variável, sendo mensal de 1927 a 1930, bimestral de 1931 a 1932, trimestral de 1933 a 1934, semestral de 1935 a 1937 e em 1945 e 1961, anual de 1938 a 1944, de 1946 a 1947 e em 1952, e quadrimestral a partir de 1951.

O referencial teórico-metodológico adotado para análise do corpus descrito é formado pela História Cultural da Leitura, em diálogo com os trabalhos sobre a história do ensino de língua portuguesa no nível secundário brasileiro, assim como pesquisas sobre a história da educação.

\section{Retórica e Poética Clássicas no Ensino Secundário Brasileiro}

A introdução da retórica clássica - enquanto interpretação escolástica de conceitos e preceitos retóricos gregos e latinos - ocorrera no Brasil durante o século XVI. Depois de ter sido reativada no movimento contra-reformista da Igreja Católica, ocasionado a partir do Concílio de Trento, a retórica constituiu uma das principais disciplinas do ensino ministrado pela Companhia de Jesus (HANSEN, 2011, p. 25-26). Nos colégios jesuítas - que aqui se instalaram em 1549 e funcionaram até 1760, data em que a Companhia foi expulsa pelo Marquês de Pombal - onde a elite colonial brasileira era educada com o fim de dirigir a sociedade, de modo a consolidar o projeto colonizador de Portugal e fortalecer os laços da Colônia com a Metrópole, ministrava-se o curso de Letras Humanas (LEITE S. J., 1938, t. I, p. 71-72).

De acordo com o Ratio studiorum de 1599, método pedagógico dos jesuítas, esse curso tinha duração média de seis ou sete anos, e abrangia gradativamente cinco classes, que culminavam com a de retórica, sendo elas: gramática inferior, gramática média, gramática superior, humanidades e retórica (FRANCA S. J., 1952, p. 47-48; LEITE S. J., 1949, t. VII, p. 154). No Brasil Colonial, além de ser institucionalizada nos colégios da Companhia de Jesus, a retórica esteve presente também nas práticas artísticas de poetas, oradores, historiadores e autores de prosa de ficção. A arte retórica praticada no ensino, na oratória e na escrita correspondia ao costume de recorrer a normas e preceitos da técnica de falar bem (tékhné rethorikè), 
descrita primeiramente por Aristóteles, e retomada em tratados romanos (ars bene dicendi), como o do autor anônimo de Ad Herennium, os textos de Cícero, a Arte Poética, de Horácio, e a Instituição oratória, de Quintiliano, etc. (HANSEN, 2015, p. 119). De acordo com Hansen (2015, p. 119), esse costume (ou consuetudo) regulava os modos particulares como os autores brasileiros coloniais memorizavam e imitavam um elenco de autores (elencha auctorum), os quais forneciam argumentos e técnicas para inventarem, disporem, ornamentarem, memorizarem e dramatizarem discursos. Até a segunda metade do século XIX, a retórica funcionou como principal modelo de representação, e continuou sendo transmitida no ensino, como é possível observar no currículo do Colégio Pedro II (HANSEN, 2011, p. 25-26).

Fundado em 1837, e concebido como estabelecimento padrão para o ensino secundário brasileiro, o Colégio Pedro II teve implantada em 1839 a primeira cadeira de Retórica do Rio de Janeiro. A partir de 1858 até 1882, conforme registrado nos programas de ensino dessa instituição, a Poética passa a ser ministrada no secundário, ou como disciplina autônoma ou estando associada à Retórica ou ainda à Literatura Nacional (SOUZA, 1999, p. 163-181). O plano de estudos de 1858 para a disciplina nomeada de "Retórica e Poética", oferecida no sétimo ano do curso secundário, prescrevia, por exemplo, "exercícios de composição, tanto em prosa como em verso, análise crítica dos clássicos portugueses; discursos, narrações, declamações, história da literatura portuguesa e nacional” (SOUZA, 1999, p. 164).

A associação entre Retórica e Poética, conforme salienta Massaud Moisés (2004, p. 384), tinha ocorrido, pela primeira vez no Brasil, em 1782, quando o Vice-Rei D. Luís de Vasconcelos fundou no Rio de Janeiro uma escola de Retórica e Poética, pondo lado a lado as duas disciplinas. Aliado a este fato, também atesta a sua junção a publicação de importantes manuais de ensino que atravessaram o século XIX, como, por exemplo, as Postilas de Retórica e Poética, do Cônego Fernandes Pinheiro, cuja $3^{\text {a }}$ edição data de 1885. Retórica e Poética seguirão juntas até o fim do século XIX e início do XX, quando ocorre a inevitável separação e o paulatino declínio dos estudos retóricos clássicos no Brasil. Contudo, apesar da extinção dessas disciplinas do currículo do secundário, preceitos da retórica e da poética clássicas continuarão a exercer influência sobre o ensino da escrita até as primeiras décadas do século XX, como apontam as sugestões presentes em livros escolares de português editados à época, como Céu, terra e mar (1914), de Alberto de Oliveira, uma antologia destinada ao uso nas aulas de português do curso secundário, e O idioma nacional na escola secundária (1935), de Antenor Nascentes, um manual de ensino de português dirigido ao professor secundarista, dos quais trataremos a seguir.

\section{O Texto Literário Como Modelo: Entre as Regras da Retórica e da Poética Clássicas e a Originalidade}

No prefácio da antologia Céu, terra e mar, de Alberto de Oliveira, publicada em 1914, a qual organizava os textos reunidos por temas - como manhãs, meios-dias, tardes, noites, estrelas, montanhas, o mar, árvores, flores, rios, florestas, monstros, incêndios, tempestades, grutas e abismos, a vida -, o autor defendia que a leitura de "páginas escolhidas" deveria servir para aumentar e aperfeiçoar as aquisições de redação e estilo. Segundo Alberto de Oliveira, a divisão dos textos selecionados por assunto visava a "confrontar as composições de cada grupo e ver como o tema é desenvolvido". Nessa confrontação, a ser realizada durante a explicação do texto lido, caberia ao professor assinalar "as belezas de ideia e de elocução [...], a correção de linguagem e estilo, [...] a propriedade dos epítetos, das imagens e metáforas, e [...] a significação exata dos vocábulos que o discípulo acaso ignor[asse]". Depois disso, conforme o autor, o aluno estaria apto a se exercitar em "composições de lavra própria sobre cada um daqueles assuntos", imitando as páginas estudadas, “ou tomando-as por modelo, sem plágio ou servilismo”. Para a realização das correções do exame de redação, no entanto, Alberto de Oliveira indicava ao professor observar a 
originalidade do trabalho do aluno, o qual deveria se apresentar mais em sua expressão ou forma do que no tema tratado (OLIVEIRA, 1914, p. 7-8).

$\mathrm{Na}$ concepção de escrita expressa no prefácio da antologia escolar Céu, terra e mar, mesclam-se, de um lado, a ideia de imitação, cujo embasamento se dá na poética clássica, e de outro, a de originalidade, surgida no século XVIII com o romantismo: o texto literário lido e explicado deveria ser imitado, porém em composições de lavra própria, sem incorrer em plágio.

A imitação, enquanto prática de escrita que consiste na cópia servil dos processos empregados pelos "clássicos", ou seja, por autores antigos que apresentaram em cada gênero, espécie ou forma literária, a criação considerada mais perfeita ou mais elevada, funda-se em Horácio, o qual, na Roma antiga, a partir de glosas sobre o pensamento de Aristóteles, decalca o conceito imitatio, originalmente apresentado como mimese pelo filósofo grego em sua Poética (MOISÉS, 2004, p. 292-294). O conceito de imitação orientou a produção literária ocidental até o final do século XVIII, quando pensadores do romantismo europeu defenderam a ideia de originalidade aliada à noção de "gênio natural", isto é, aquele que, por um prodígio ou dom nato, é capaz de produzir obras de arte únicas e inimitáveis em seu gênero. Sob o conceito de originalidade ou gênio natural, estabelecia-se uma noção libertária de criação estética, que promovia uma ruptura com as regras da imitatio da poética clássica (ABRAMS, 2010, p. 250-264).

Durante a vigência da imitatio, que ocorreu desde a Antiguidade até o século XVIII, vigorava a noção greco-romana de autoria como auctoritas (autoridade). Segundo a auctoritas, o auctor (autor) era o artífice que executava sua arte por meio de uma técnica (ars) formada por regras precisas de articulação e, assim, fornecia exemplos de um uso considerado autorizado e virtuoso a ser imitado (HANSEN, 1992, p. 18-29). Com o romantismo, juntamente com a ideia de originalidade, instaura-se uma nova noção de autoria, e o autor passa a representar uma individualidade expressiva e criativa, de modo que, em sua escrita, torna-se desnecessário o reconhecimento de uma filiação a uma tradição de autoridades que o tivessem antecedido, conforme prescrevia outrora a poética clássica (ABRAMS, 2010, p. 250-264).

Já no início do século XVIII, aproximadamente em 1720 na Inglaterra, dá-se ainda a construção da autoria com base nos direitos de propriedade do autor sobre sua obra, o que, consequentemente, é acompanhado do surgimento de fenômenos como plágio e copyright. $\mathrm{O}$ argumento usado, nesse período, para o tratamento da obra literária como propriedade intelectual de um autor específico, baseava-se, de um lado, na consideração de que a arte literária, assim como as artes mecânicas, era produto do trabalho humano, e de outro, na categoria estética da originalidade, que atribuía à composição literária características relacionadas à singularidade de seu estilo, sentimento e linguagem (CHARTIER, 2012, p. 45-47).

Desse modo, nas recomendações sobre escrita, apresentadas na antologia escolar Céu, terra e mar, de Alberto de Oliveira, nota-se certa ambivalência na apropriação feita, ao mesmo tempo, de dois conceitos que, por sua natureza, se oporiam: o de imitação, advindo da poética clássica, e o de originalidade, concebido no âmbito do romantismo.

A ambivalência na apropriação de duas situações que naturalmente tenderiam a se opor, como a obediência às regras da retórica e da poética clássicas e o uso da originalidade, a qual, por meio da ideia do gênio natural, buscava justamente o fim da submissão às regras de criação artística da poética e da retórica clássicas, pode ser observada também no manual do professor O idioma nacional na escola secundária, de Antenor Nascentes, publicado em 1935.

Em suas recomendações sobre escrita, assim como Céu, terra e mar, de Alberto de Oliveira, O idioma nacional na escola secundária, de Antenor Nascentes, principia sugerindo ao professor que o ensino da escrita deveria vir depois do ensino da leitura. Para o autor, a aula de leitura, a qual consistiria primeiramente em ler o texto em voz alta, e depois em explicar o sentido do trecho lido, colocar em ordem direta as inversões, substituir os vocábulos por sinônimos, e por vezes converter o verso em prosa, apresentava a 
grande vantagem de aumentar o vocabulário, funcionando como "colheita do material a servir mais tarde à expressão das ideias". Antenor Nascentes vincula a qualidade da escrita à quantidade de leituras feitas, segundo a premissa de que escrevem bem os que muito leem (NASCENTES, 1935, p. 73).

Quanto à prática da escrita, propriamente dita, Antenor Nascentes sugere o emprego das três operações retóricas para a composição de discursos, ou seja, a invenção, a disposição e a elocução. A origem dessas três operações remonta à Antiguidade greco-romana, sendo primeiramente descrita na Arte Retórica, de Aristóteles: "Três são as questões relativas ao discurso, que precisam ser versadas a fundo: a primeira, donde se tirarão as provas [invenção]; a segunda, o estilo que se deve empregar [elocução]; a terceira, a maneira de dispor as diferentes partes do discurso [disposição]" (ARISTÓTELES, III, I, 1979, p. 211).

A primeira fase da elaboração do discurso, conforme Heinrich Lausberg (2004, p. 91) aponta em Elementos de retórica literária, é a invenção, isto é, "atos de encontrar pensamentos adequados à matéria, conforme o interesse [...]". Segundo este autor, interligadas à invenção, aparecem ainda a disposição e a elocução: a disposição é constituída "pela escolha e ordenação favoráveis [...], as quais, no discurso concreto, se fazem dos pensamentos, das formulações linguísticas e das formas artísticas"; a elocução "é a expressão linguística dos pensamentos encontrados pela invenção", estando sujeita à regras da ars bene loquendi (gramática) e da ars bene dicendi (arte retórica) (LAUSBERG, 2004, p. 94- 114).

Para Antenor Nascentes, a mais importante dentre essas três operações retóricas é a invenção, e por esse motivo, o autor da obra didática aconselha ao professor de português: "Possua o aluno alguma inteligência, alguma cultura, estude o assunto, que a mão obedecerá ao cérebro” (NASCENTES, 1935, p. 99-100). E, a fim de corroborar o seu argumento, Nascentes recorre ainda a uma máxima latina relacionada à arte retórica, "Rem tene, verba sequentur" ["Domine o assunto, as palavras sucederão"], e a Boileau, "Ce que l'on conçit bien s'énonce clairement / Et les mots pour le dire arrivent aisément" [“O que se concebe bem se enuncia claramente / E as palavras para o dizer chegam facilmente"]. A referência à Arte Poética (1674), de Boileau, obra que reproduz as regras da poética clássica da Antiguidade greco-romana, e que teve grande prestígio durante o classicismo na França, nos séculos XVII e XVIII, é usada por Antenor Nascentes para rebater a ideia de que a criação do pensamento é algo espontâneo ocorrido durante a escrita. Nesse sentido, Antenor Nascentes demonstra uma adesão ao conceito clássico de invenção, segundo o qual a inventio não deve ser compreendida como um processo de criação, mas sim como um encontrar, por meio da recordação, os pensamentos aptos ao discurso, pré-existentes na memória do escritor (LAUSBERG, 2004, p. 91).

Reconhecendo que a retórica clássica já havia caído em desuso, no momento em que $O$ idioma nacional na escola secundária (1935) era produzido, Antenor Nascentes, em suas recomendações para o ensino da escrita, apropria-se de alguns preceitos retóricos que julgava ainda cabíveis ao seu tempo, como as já mencionadas operações necessárias à elaboração de discursos (invenção, disposição e elocução), ao mesmo tempo em que rechaça outros preceitos, como o de imitação, valorizando, em seu lugar, a originalidade.

Nas sugestões para o quinto ano ginasial, apresentadas em $O$ idioma nacional na escola secundária, o professor é orientado a iniciar o trabalho pelos estudos literários. Durante os exercícios de análise do estilo, realizados na leitura e explicação do texto, o professor observaria as figuras de retórica que, segundo Nascentes, embora fossem tomadas como "velhas", possuíam emprego ainda atual, devendo por isso ser citadas de vez em quando pelo homem culto. Essas figuras de retórica, as quais serviam ao ornamento do discurso pelas regras da elocução, seriam colhidas na leitura de textos literários de autores consagrados, tanto brasileiros como portugueses. As composições escritas, elaboradas após a leitura, poderiam "versar sobre assuntos elevados, temas abstratos, atualização de trechos clássicos, transcrição de verso em prosa literária, tradução literária de belos trechos escritos em outras línguas” (NASCENTES, 1935, p. 68). 
Favorável à noção de gênio natural, isto é, aquele que possui o talento literário como um dom raro e espontâneo, Antenor Nascentes procura valorizar a escrita desentranhada da experiência vivida pelo indivíduo, ao mesmo tempo em que critica a imitação que, para o autor, se baseia tão somente em lembranças de frases lidas, de metáforas decoradas, de lugares comuns. Como foi dito anteriormente, pelas regras da poética clássica, exigia-se que se reconhecessem, nos escritos de um determinado autor, processos de criação artística filiados a uma tradição de autoridades que o tivessem precedido, por meio do emprego de formulações linguísticas memorizadas de auctores do passado. Contrários a essa regra da imitatio tinham se posicionado os românticos europeus do final do século XVIII, ao introduzirem o conceito de originalidade.

No texto didático de Antenor Nascentes, a essa noção de originalidade, surgida com o romantismo, associa-se também certa pedagogização do ensino da escrita. Apoiado nas ideias de Afrânio Peixoto, expostas no livro Ensinar a ensinar, Antenor Nascentes recomenda ao professor de português a aplicação de exercícios de redação sobre temas do cotidiano, por meio da composição de "cartas, pedidos, pequenas cenas ou descrições de objetos muito conhecidos", que favoreçam a manifestação sincera, no papel, de ideias originais e sentimentos próprios, elementos os quais, segundo Peixoto citado por Nascentes, seriam capazes de tornar a obra escrita interessante.

Essa preocupação com um tipo de ensino de escrita que suscitasse uma expressão original do pensamento a partir de elementos do dia a dia do aluno, presente nessas orientações, aparece também no programa de português de 1931, emitido no âmbito da Reforma Francisco Campos, o qual tinha entrado em vigor pouco antes da publicação de O idioma nacional na escola secundária, ocorrida em 1935. Tanto as recomendações de $O$ idioma nacional na escola secundária como as do programa de português de 1931 parecem refletir algumas das ideias sobre metodologias de ensino oriundas das ciências de referência da pedagogia, como a psicologia da educação. Segundo Rosa Fátima de Souza (2008, p. 155), mudanças internas às disciplinas, como as observadas na disciplina de português, nesse período, eram resultantes da incorporação de modelos pedagógicos que circularam primeiramente nas escolas normais e nas escolas secundárias, por iniciativa de alguns professores, e que se tornaram mais sistemáticos, na década de 1930, de modo a assentar as bases preliminares e oficiais de uma pedagogia da escola secundária com a Reforma Francisco Campos, pela atuação de educadores vinculados aos órgãos de administração do ensino, aos Institutos de Educação e às Faculdades de Filosofia, Ciências e Letras.

Somente na $4^{a}$ série começará a redação livre, dando-se-lhe daí por diante, até o termo do curso, maior atenção. Cerca de três quartas partes do tempo letivo deverá ser destinado à correspondência, às descrições e narrações, entremeadas com exercícios de estilo e análise literária dos textos (Programa de Português de 1931 apud BICUDO, 1942, p. 138).

No programa de português de 1931, assim como em O idioma nacional na escola secundária, a leitura assume o importante papel de subsídio à escrita. De acordo com as disposições oficiais, o professor deveria indicar "ao aluno, tanto quanto possível, as leituras a que convém recorrer a fim de melhor executar [os trabalhos de composição escrita]" (Programa de Português de 1931 apud BICUDO, 1942, p. 138). Concorda com isso Antenor Nascentes, ao afirmar que "o melhor auxiliar que o professor tem a seu dispor para ensinar composição é [...] a leitura” (NASCENTES, 1935, p. 106-107).

A revisão, etapa final do ensino da escrita, é vista, tanto no programa de português quanto no livro escolar de Nascentes, como uma fase necessária ao acabamento do texto escrito. Pelo documento oficial, na correção dos trabalhos de composição escrita, o professor deveria "assinalar todos os erros, classificando em lista especial os mais comuns (erros de ortografia, pontuação, concordância, regência, 
impropriedades, etc.)". Já em O idioma nacional na escola secundária, a recomendação para a revisão inclui a supressão de palavras supérfluas, mudança de frases, rearranjo de ideias, tarefas consideradas por Nascentes apropriadas a "todo escritor cuidadoso".

Para sustentar a importância da revisão do texto escrito, Antenor Nascentes apoia-se novamente na Arte Poética de Boileau, da qual extrai a seguinte citação: Vingt fois sur le métier remettez votre ouvrage / Poilissez-le sans cesse et le repolissez. [Vinte vezes submeta ao trabalho sua obra / Polindo-a sem cessar e polindo-a mais uma vez]. Os versos de Boileau, ao exprimirem a ideia de uma constante reelaboração do trabalho artístico, numa atividade incessante, a fim de se alcançar a perfeição, reproduzem a seu modo, conselhos sobre a criação artística outrora expressos por Horácio em sua Arte Poética: "Vós, volvei os modelos gregos com mão noturna, volvei com mão diurna" (HORÁCIO, 1993, p. 33). Dessa forma, além de se apropriar de preceitos da retórica/poética clássicas relacionados às três operações necessárias à elaboração de discursos (invenção, disposição e elocução), como vimos anteriormente, Antenor Nascentes apresenta ainda certa filiação à retórica/poética clássicas no que concerne à prática da revisão da composição escrita (NASCENTES, 1935, p. 106-107).

Assim, durante as primeiras décadas do século XX, nas orientações para o ensino da escrita nas aulas de português do curso secundário, encontramos alguns preceitos da retórica e poética clássicas mesclados à noção de originalidade. Em Céu, terra e mar, de Alberto de Oliveira, publicado em 1914, sugere-se a imitação dos autores reunidos na antologia escolar, os quais deveriam ser tomados por modelo, mas numa escrita que fosse original. Em O idioma nacional na escola secundária, de Antenor Nascentes, editado em 1935, embora a prática da imitação seja abandonada, outros preceitos retórico-poéticos são recomendados, como as três operações para a elaboração de discursos (a invenção, a disposição e a elocução), ao mesmo tempo em que é preconizado um tipo de ensino de composição que suscite a original expressão do pensamento do aluno. A partir dos anos de 1930, como é possível perceber no manual do professor elaborado por Antenor Nascentes e no programa de português emitido junto à Reforma Francisco Campos de 1931, à noção de originalidade associam-se também certas ideias da psicologia da educação. Essa associação dará origem a uma nova concepção de escrita, que procura valorizar a criatividade, e que nas décadas seguintes, estará na base das orientações sobre o ensino de redação, em livros escolares de português para o ginásio e em artigos de revistas de ensino que tratam do assunto, conforme veremos adiante.

\section{A Redação: Criatividade Motivada Pela Leitura}

Nas décadas de 1950 e 1960, apresenta-se em livros escolares de português e em artigos de revistas de ensino uma nova concepção de escrita, a qual se pode definir como uma manifestação criativa da imaginação motivada pela leitura. Em sua fundamentação, encontra-se a ideia de originalidade aliada a certas noções da psicologia da educação, associação que já tinha sido esboçada anteriormente em livros escolares de português e em programas oficiais de ensino da década de 1930. Essa concepção de escrita norteará, por exemplo, as orientações sobre o ensino de redação presentes no artigo "Importância da composição", publicado na Revista de Educaşão em junho de 1951, e na coleção didática para o ginásio Português através de textos, de Magda Soares, editado nos anos de 1960.

Quando o breve artigo "Importância da composição", de autoria de Aires da Mata Machado Filho, era veiculado em junho de 1951 no periódico educacional paulista Revista de Educação, este já havia sido publicado no jornal O Estado de São Paulo no mesmo mês e ano. No texto, Machado Filho ao refletir sobre o ensino da escrita, aponta dois aspectos especialmente relevantes: a constatação de que o escrever, assim como o falar e o ler, insere-se em uma dinâmica comunicativa; e a confiança no papel motivacional da leitura 
e da fala para a composição escrita. Segundo o autor, no "binômio compreender e comunicar", integramse fala, leitura e escrita, e nessas três atividades, portanto, deveria centrar-se o objetivo do ensino de língua.

O afã de compreender explica-se pela necessidade humana de comunicar. Compreender para comunicar equivale a redigir. [...].

$[\ldots]$

Para compreender, é preciso ler. Mas ler de verdade, isto é, escolher. Quem aprende a falar como se deve, nunca deixa de ler como se deveria: com proveito próprio e aprazimento alheio. O domínio da língua, que é fala, habilita a escrever. No âmbito do binômio compreender e comunicar funcionam as atividades que se completam: falar, ler e escrever (MACHADO FILHO, 1951, p. 101).

Baseando-se nas ideias do eminente linguista Serafim da Silva Neto sobre "linguagem adquirida" e "linguagem transmitida", Machado Filho lida com um conceito de comunicação, cuja dinâmica se assenta em dois polos: de um lado, está o compreender, que abarca a leitura, perfazendo a linguagem adquirida; e de outro, o comunicar, que engloba a fala e a escrita, constituindo a linguagem transmitida. E é nesta dinâmica que Aires da Mata Machado Filho localiza a importância do exercício de composição enquanto tarefa escolar, visto que, sendo a composição escrita "parte da linguagem sujeita à transmissão", esta seria responsável por "integrar o indivíduo no grupo social a que pertence, habilitando-o às trocas expressionais indispensáveis". Utilizando-se de tais argumentos, o articulista procura então convencer o professor da necessidade de o aluno realizar exercícios frequentes de escrita, o que parece se assemelhar, de certo modo, a um treino: para o autor, "aprende-se a escrever escrevendo", e a falta de destreza na escrita estaria relacionada à falta ou deficiência dos exercícios de escrita na sala de aula. No ensino da escrita, funcionariam como atividades subsidiárias "a leitura bem feita, que ensina compreender", e a "composição oral, que aviventa a redação escrita". O sucesso na escrita dependeria, contudo, da motivação para tal:

No doseamento dos exercícios ocorre demasia ou deficiência. Entre nós a primeira alternativa cifra-se em possibilidade teórica. Em todo o caso, sempre cabe prevenir o erro da composição a todo o preço, sem motivação. Evidentemente, a nada conduz. O comum, porém, é registrar-se a segunda alternativa - a deficiência. Também, se os professores, sem descontinuar, desde o curso primário até o secundário, em todas as séries, deixarem de mandar fazer composições escritas os alunos não aprenderão a escrever. Em razão da falta desse exercício muitos, entre nós, quando forçados a redigir alguma coisa pelas necessidades da vida deixam a impressão de que nunca estiveram na escola (MACHADO FILHO, 1951, p. 102).

A relevância do aspecto motivacional para a escrita, apontada por Machado Filho, será preponderante em recomendações para o ensino de redação apresentadas em livros escolares de português editados posteriormente, na década de 1960, como a coleção didática Português através de textos, voltada ao ginásio, de Magda Soares. Para a autora: "O texto forma o clima afetivo necessário à criação, desperta interesses e a redação passa a responder a uma necessidade interior de expressar-se sobre determinado assunto" (SOARES, 1969, p. 49).

No manual do professor da referida coleção, Magda Soares procura esclarecer o seu leitor, o professor de português, sobre a importância da escolha dos temas dos textos reunidos nos livros do aluno da primeira, segunda, terceira e quarta série ginasial, visto que esses temas funcionariam como subsídio à escrita: os temas da redação seriam sugeridos pelo texto lido, discutido e comentado em sala de aula previamente com os alunos. Assim, segundo Soares, a escolha dos textos procurava fugir aos temas genéricos, abstratos, vagos, incapazes de despertar no aluno interesse ou vontade de escrever, tais 
como "a primavera, um dia de chuva, um passeio no campo, a caridade, etc.", cuja vantagem seria apenas a de inibir a possibilidade de criação, levando "ao lugar comum, ao convencionalismo, à trivialidade". Ao contrário, os textos da coleção Português através de textos, ao tratarem de temas mais próximos do cotidiano do adolescente, apresentavam o potencial de "acordar" nos alunos "ideias, reminiscências, vivências passadas e, sobretudo, vontade de escrever” (SOARES, 1969, p. 49).

A coleção didática Português através de textos, nos livros para a primeira série (1969, $10^{a}$ edição), segunda série (1967, 2a edição), terceira série (1969, $2^{\text {a }}$ edição), e quarta série, dentro de cada assunto gramatical a ser desenvolvido em sala de aula, apresentava um texto literário para estudo. Entre os autores desses textos selecionados, além daqueles já consagrados pela história e crítica literária brasileira, como Machado de Assis, José Lins do Rego, Carlos Drummond de Andrade, Manuel Bandeira, Guimarães Rosa, cujos excetos foram escolhidos pela temática próxima ao cotidiano do aluno, encontram-se ainda autores que se dedicaram à escrita de uma literatura para a infância e juventude, como Monteiro Lobato, Viriato Corrêa, Cecília Meireles e Clarice Lispector.

A “apreciação de poema”, por sua vez, recebe uma atenção especial, nesta coleção. No livro da segunda série, poemas como "Um passarinho", de Vinícius de Moraes, "Lua cheia”, de Cassiano Ricardo, "Ou isto ou aquilo", de Cecília Meireles, "As amazoninhas", de Ribeiro Couto, intercalam as sequências de estudo da gramática e de texto. No livro da $3^{a}$ série, catorze poemas são reunidos ao final do impresso didático, constituindo o que a autora denominou de "antologia poética". E no livro da quarta série, do mesmo modo que no da $3^{a}$ série, a "antologia poética" encerra o material didático. Nos dois primeiros livros mencionados, ou seja, os destinados à $2^{\mathrm{a}}$ e $3^{\mathrm{a}}$ séries, como explica a própria autora no manual do professor da mesma coleção, "os poemas vêm acompanhados de perguntas de apreciação, que procuram orientar o aluno na percepção da mensagem poética”, procedimento que foi abandonado no livro da $4^{\text {a }}$ série, por julgá-lo desnecessário.

A inclusão de excertos extraídos da literatura infanto-juvenil, nos livros do aluno da coleção Português através de textos, apresentava a preocupação de oferecer uma temática que girasse em torno de assuntos relacionados à infância e à juventude, à escola, à família, à natureza, às brincadeiras, etc.; dos quais, por sua vez, se derivariam os temas da redação. Assim, ao comentar sobre os temas da redação, propostos nos livros da primeira e segunda série de sua coleção, a autora afirma no manual do professor:

Como os textos foram escolhidos de acordo com os interesses e as motivações habituais e frequentes em pré-adolescentes (11 a 13 anos), também os temas de redação, que deles derivam, atendem a esses interesses e a essas motivações (SOARES, 1969, p. 49).

A seleção de excertos literários, cuja temática tratasse do cotidiano do aluno já se fazia notar em livros escolares para o ginásio da década de 1950. Entretanto, é a partir da década de 1960, que se observa uma inclusão nos livros escolares destinados a esse segmento de ensino, como Português através de textos, de Magda Soares, de uma literatura infanto-juvenil, ou seja, de uma literatura elaborada especificamente para o público infantil e adolescente. De acordo com Nelly Novaes Coelho (1991, p. 256-258), grande parte dos escritores que tinham se iniciado nesse tipo de literatura durante os anos de 1950 entra numa "fase de produção essencialmente enriquecedora", no decênio de 1960. Ainda segundo Coelho (1991, p. 256-258), essa produção pode ser explicada, em parte, pela crescente demanda de livros literários (que será acelerada nos anos de 1970), a qual, por sua vez, era suscitada, de um lado, pela expansão significativa do ensino público, e de outro, pelas próprias orientações curriculares para o ensino da leitura ensejadas pela Lei de Diretrizes e Bases da Educação Nacional (Lei no 4.024, de 20/12/1961), principalmente aquelas relativas à escola primária, como as apresentadas, por exemplo, no Programa da Escola Primária 
do Estado de São Paulo (fixado em 31/05/1967 por um Grupo de Trabalho nomeado pela Secretaria da Educação de São Paulo).

No livro da primeira série do ginásio, conforme descrito por Magda Soares novamente no manual do professor, temas relacionados ao sonho e à fantasia, os quais tinham o intuito de desenvolver a imaginação, orientariam a elaboração, por exemplo, de uma descrição de uma viagem a um país imaginário, sugerida pela leitura do texto "A ideia do Visconde" (O Sítio do Pica-pau Amarelo, de Monteiro Lobato), ou de uma descrição antropomorfizada de um animal, a partir de sentenças norteadoras do tipo "como seria, se fosse um cachorro", ou "como seria, se fosse uma formiga", construídas a partir do texto "Sesta", de Augusto Meyer. Contemplam-se também, neste livro, temas concernentes ao mundo da infância que, segundo a autora, levariam o aluno a voltar-se para a sua própria vida e analisar suas experiências passadas, como, por exemplo, "que ideia você fazia do ginásio e de sua escola antes de começarem as aulas?", desentranhados do texto "Entrada para a escola", de Viriato Corrêa. Aparecem ainda, no primeiro livro da coleção, temas para descrições de paisagens ou de pessoas, as quais deveriam se fundamentar na observação da realidade, a fim de evitar repetição vazia e de experiências alheias ou de lugares comuns, como, por exemplo, "O que vejo da minha janela", sugerido pelo texto "Arte de ser feliz", de Cecília Meireles, e "crianças que trabalham", sugerido pelo texto "Meninos carvoeiros", de Manuel Bandeira.

Os temas de redação propostos no livro da segunda série seguiriam basicamente os mesmos princípios do que era apresentado no livro da primeira série. A inovação, entretanto, se dá no livro da terceira série, com a inclusão de temas para dissertação, os quais passam a constar com maior frequência no livro da quarta série, tendo em vista que, para a autora, "já estão agora os alunos suficientemente amadurecidos para este tipo de redação" (SOARES, 1969, p. 53).

São exemplos de temas de dissertação no livro: A Amazônia, O fogo, amigo e inimigo do homem, Crendices populares. O primeiro faz apelo aos conhecimentos geográficos e econômicos do aluno; o segundo exige uma reflexão sobre o papel do fogo na vida homem; o terceiro exige conhecimentos de aspectos da cultura brasileira e pede uma reflexão sobre a origem e natureza das crendices populares (SOARES, 1969, p. 54).

No livro da quarta série, os temas da redação, sempre extraídos dos textos lidos, parecem assumir uma dimensão ética, que visava a formar moralmente o aluno, conforme justifica a autora: "[...] na quarta série, temas que exigem dissertação aparecem com frequência, e visam, sobretudo, a levar o aluno a um processo de valoração [...]" (SOARES, 1969, p. 55). Assim pretendia, por exemplo, o tema extraído do texto "Amor e outros males", de Rubem Braga. A partir de um conceito de amor proposto no texto lido (sentimento incômodo, pior que uma bursite), o aluno deveria redigir uma dissertação em que formulasse seu próprio conceito de amor, o que, para Magda Soares, o levaria a esclarecer ideias e pontos-de-vista de que provavelmente não estaria muito consciente.

Como os textos reunidos nos livros do aluno da primeira, segunda, terceira e quarta série da coleção Português através de textos são em sua maioria narrativas curtas, os termos "descrição" e "dissertação", empregados por Magda Soares para definir os textos a serem escritos pelos alunos, parecem referir-se a sequências ou partes do texto mais predominantes na estrutura de um texto narrativo, podendo este ser, de acordo com essa ideia, ou mais descritivo ou mais dissertativo. A estrutura de um texto, ou sua forma de organização, seria apreendida pelo aluno a partir de um texto lido previamente (com algum auxílio do professor), de modo que este fosse capaz de reproduzi-la em sua redação. Quanto ao planejamento do texto, tarefa preparatória para a escrita, o professor ajudaria a classe apenas nas primeiras atividades de escrita, a fim de preservar a originalidade de cada indivíduo, evitando a influência de ideias que não lhe fossem próprias: 
Nas primeiras redações, convém ainda discutir previamente com os alunos o plano de desenvolvimento das ideias; mostrando como os textos estudados apresentam sempre uma estrutura, em que o pensamento se organiza com lógica, insistir na necessidade de que se planeje a redação antes de começar a escrever. Poderá o professor, inclusive, algumas vezes, construir em sala o plano, com a colaboração dos alunos. Entretanto, fá-lo-á apenas até que alguns aprendam a construir um plano, pois o planejamento coletivo pode destruir a originalidade e roubar o caráter individual da redação (SOARES, 1969, p. 58-59).

De acordo com as orientações sobre os exercícios de redação, a serem realizados a partir dos livros do aluno da coleção ginasial Português através de textos, os temas de redação parecem funcionar como uma espécie de mote extraído de um texto previamente lido na sala de aula. Esses temas, por sua vez, estando próximos do cotidiano do aluno, funcionariam como o principal motor para a escrita original. A concepção de escrita, com que lida Magda Soares, assemelha o escrever a um ato criativo, despertado por interesses próprios dos alunos, cujo objetivo fundamental seria o de comunicar o mundo interior do aluno ao mundo exterior que o rodeia. $\mathrm{O}$ aluno deveria escrever não para cumprir uma atividade rotineira ou para satisfazer a uma exigência do professor, mas sim para responder a uma necessidade interior, a um interesse pessoal (SOARES, 1969, p. 58).

A noção de escrita como expressão da criatividade individual mantém uma estreita relação com ideias da psicologia da educação baseadas na psicologia experimental, que, juntamente com a teoria sociológica de Durkheim e o pragmatismo de Dewey, fundamentavam metodologias de ensino propugnadas pela Escola Nova. Tendo circulado no Brasil a partir dos anos de 1920, o ideário escolanovista, que tinha como uma de suas premissas a de que o aluno constitui o centro dos processos de aprendizagem, passou a compor posteriormente os currículos de formação do professor secundarista, influenciando também a formação de Magda Soares, realizada em Letras Neolatinas, entre 1950 e 1953, na Universidade Federal de Minas Gerais, como a própria autora descreve em sua autobiografia intelectual (SOARES, 2001, p. 5556). Nesse sentido, o contato travado por Magda Soares com as ideias da Escola Nova, durante o curso de licenciatura, pode ter impactado a elaboração de Português através de textos, e, por conseguinte, a concepção de escrita presente na referida coleção.

Diferentemente do que tinha sido exposto por Aires da Mata Machado Filho, em seu artigo "Importância da composição", veiculado na Revista de Educaşão em junho de 1951, o qual tomava a composição escrita inserida numa dinâmica comunicativa, ligada a um contexto mais amplo, em Português através de textos, a esfera comunicativa da redação aparece restrita à sala de aula, que constituiria o público ouvinte do autor, para o qual seu texto seria lido em voz alta:

[...] ao receber as redações, [o professor] pedirá a alguns alunos que leiam em voz alta o trabalho, de modo que, ao escreverem, possam sentir que o fazem para um público - os colegas - e sintam a funcionalidade do trabalho (SOARES, 1969, p. 58, grifo da autora).

Por outro lado, do mesmo modo que em Machado Filho há a ideia de que o desenvolvimento da escrita se dá por um treino constante, ou seja, "aprende-se a escrever escrevendo", sem a necessidade de aplicação de um método sistemático de escrita, em Magda Soares, há a ideia de que é necessária apenas a motivação, exercida pela leitura de um texto, para que a redação se desenvolva de forma original e individual pelo aluno. 


\section{Considerações Finais}

No que concerne ao ensino da escrita no curso secundário, durante as primeiras décadas do século XX, encontramos, em livros escolares produzidos no período, alguns preceitos da retórica e poética clássicas mesclados à noção de originalidade. É o que ocorre, por exemplo, em Céu, terra e mar, de Alberto de Oliveira, uma antologia escolar destinada às séries ginasiais, publicada em 1914, e em O idioma nacional na escola secundária, de Antenor Nascentes, um manual do professor de português, editado em 1935. Na antologia de Alberto de Oliveira, sugere-se a imitação dos autores de literatura nela reunidos, os quais deveriam ser tomados por modelo, contudo numa escrita que fosse original. No manual de Antenor Nascentes, embora a prática da imitação seja rechaçada, outros preceitos retórico-poéticos são recomendados, como as três operações para a elaboração de discursos (a invenção, a disposição e a elocução), ao mesmo tempo em que é preconizado um tipo de ensino de composição que suscite a original expressão do pensamento do aluno. Nas sugestões para o ensino da escrita apresentadas tanto em Céu, terra e mar, como em O idioma nacional na escola secundária, nota-se certa ambivalência na apropriação feita, simultaneamente, de conceitos que, por sua natureza, tenderiam a se opor: de um lado, os de imitação, invenção, disposição e elocução, advindos da retórica e poética clássicas, e de outro, o de originalidade, concebido no âmbito do romantismo justamente com o intuito de eliminar a obediência às regras de composição da tradição clássica e valorizar a criação artística individual.

Tendo perdurado como disciplina formal do currículo do Colégio Pedro II até o final do século XIX, os preceitos da Retórica podem ter sido incorporados à disciplina Português, conforme sugere a análise dos livros de Alberto de Oliveira e Antenor Nascentes. Essa conservação de preceitos retóricopoéticos em textos didáticos voltados ao ensino de português, elaborados ainda nos primeiros decênios do século XX, atesta a importância que a arte retórica assumiu no curso secundário brasileiro, desde a sua implantação no século XVI com o ensino jesuítico.

A partir dos anos de 1930, à noção de originalidade, surgida com o romantismo, associase também certa pedagogização do ensino da escrita, apoiada na psicologia da educação, ciência de referência da Pedagogia. A relação entre originalidade e psicologia da educação passa então a compor as recomendações do programa de português emitido junto à Reforma Francisco Campos de 1931, na medida em que se preconiza a aplicação de exercícios de redação sobre temas do cotidiano do aluno, o que é seguido por livros escolares, como O idioma nacional na escola secundária, de Antenor Nascentes.

Nas décadas seguintes, essa associação dá origem a uma nova concepção de escrita, que procura valorizar a criatividade, a qual passa a integrar as orientações sobre o ensino de redação, em artigos de revistas de ensino, como "Importância da composição", de Aires da Mata Machado Filho, veiculado na Revista de Educação em junho de 1951, e em livros escolares de português para o ginásio, como a coleção didática Português através de textos, de Magda Soares, elaborado na década de 1960. A concepção de escrita, com que lidam Machado Filho e Magda Soares, assemelha o escrever a um ato criativo, despertado por interesses próprios dos alunos, cujo objetivo fundamental seria o de comunicar o mundo interior do aluno ao mundo exterior que o rodeia. De acordo com esses dois autores, o desenvolvimento da escrita consistiria num treino constante, sem a necessidade de aplicação de um método sistemático de ensino, sendo necessária apenas a motivação, exercida pela leitura prévia de um texto, para que a redação se desenvolva de forma original e individual pelo aluno.

Dessa forma, a análise das obras didáticas mencionadas acima, sugere que, no ensino da escrita nas aulas de português do curso secundário podem ter havido, primeiramente, práticas que mobilizavam conhecimentos retórico-poéticos mesclados à ideia de originalidade, até aproximadamente a primeira metade do século XX; e que, posteriormente, aprofundando-se a noção de originalidade, passaram a valorizar a criatividade individual na elaboração da escrita, nas décadas de 1950 e 1960. 


\section{REFERÊNCIAS}

ABRAMS, Meyer Howard. O espelho e a lâmpada: teoria romântica e tradição crítica. Tradução Alzira Vieira Allegro. São Paulo: Editora Unesp, 2010.

ARISTÓTELES. Poética. Tradução de Eudoro de Sousa. Lisboa: Imprensa Nacional - Casa da Moeda; F.C.S.H. da Universidade Nova de Lisboa, 1986.

BICUDO, Joaquim de Campos. O ensino secundário no Brasil e sua atual legislação (de 1931 a 1941 inclusive). São Paulo: AIFES, 1942.

CATANI, Denice Barbara. A imprensa periódica educacional: as revistas de ensino e o estudo do campo educacional. Educação e Filosofia, Uberlândia, v. 10, n. 20, p. 115-130, jul./dez. 1996.

CATANI, Denice Barbara \& SOUSA, Cynthia Pereira de (orgs.). Imprensa periódica educacional paulista (1890-1996): catálogo. São Paulo: Plêiade, 1999.

CHARTIER, Roger. História intelectual do autor e da autoria. In: FAULHABER, Priscila e LOPES, José Sérgio Leite (orgs.). Autoria e história cultural da ciência - Roger Chartier. Rio de Janeiro: Beco do Azougue, 2012.

COELHO, Nelly Novaes. Panorama histórico da literatura infantil/juvenil: das origens indo-europeias ao Brasil contemporâneo. São Paulo: Editora Ática, 1991.

HALLEWELL, Laurence. O livro no Brasil: sua história. Tradução de Maria da Penha Villalobos, Lólio Lourenço de Oliveira e Geraldo Gerson de Souza. São Paulo: Editora da Universidade de São Paulo, 2005.

HANSEN, João Adolfo. Autor. In: JOBIM, José Luis (org.). Palavras da crítica. Rio de Janeiro: Imago, 1992.

HANSEN, João Adolfo. A civilização pela palavra. In: LOPES, Eliane Marta Teixeira; FARIA FILHO, Luciano Mendes de; VEIGA, Cynthia Greive. 500 anos de educação no Brasil. Belo Horizonte: Autêntica, 2011.

HANSEN, João Adolfo. Política católica, instituição retórica e oratória sacra no Brasil colonial. In: COURTINE, Jean-Jacques; PIOVEZANI, Carlos (orgs.). História da fala pública: uma arqueologia dos poderes do discurso. Petrópolis: Editora Vozes, 2015.

HORÁCIO. Arte Poética. Tradução de Dante Tringali. São Paulo: Musa Editora, 1993.

LAUSBERG, Heinrich. Elementos de retórica literária. Tradução de R. M. Rosado Fernandes. Lisboa: Fundação Calouste Gulbenkian, 2004.

LEITE S. J., Pe. Serafim. História da Companbia de Jesus no Brasil. Lisboa: Portugália; Rio de Janeiro: Civilização Brasileira, 1938-1949, tomos I, II, VII.

LEMME, Paschoal. Memórias de um educador: infância, adolescência, mocidade. Brasília: Inep, 2004, volume I. 
MACHADO FILHO, Aires da Mata. Importância da composição. Revista de Educação, São Paulo, Departamento de Educação, Secretaria de Estado dos Negócios da Educação de São Paulo, v. 37, n. 59, p. 101-102, jun. 1951.

MOISÉS, Massaud. Dicionário de termos literários. São Paulo: Cultrix, 2004.

NASCENTES, Antenor. O idioma nacional na escola secundária. São Paulo: Melhoramentos, 1935.

OLIVEIRA, Alberto de. Céu, terra e mar: prosa e verso. Rio de Janeiro; São Paulo; Belo Horizonte: Livraria Francisco Alves, 1914.

PFROMM NETTO, Samuel et al. O livro na educação. Rio de Janeiro: Primor/Instituto Nacional do Livro, 1974.

RAZZINI, Marcia de Paula Gregorio. O espelho da nação: a antologia nacional e o ensino de português e de literatura (1838-1971). São Paulo. Instituto de Estudos da Linguagem - Universidade Estadual de Campinas. Tese (Doutorado em Letras) - Curso de Teoria Literária. Linha de Pesquisa: Teoria Literária. São Paulo, Campinas, 2000.

SOARES, Magda. Português através de textos. Manual do professor. Curso ginasial. 7 a edição. Belo Horizonte: Editora Bernardo Álvares S/A, 1969.

SOARES, Magda. Português através de textos. $1^{\mathrm{a}}$ série. $10^{\mathrm{a}}$ edição. Belo Horizonte: Editora Bernardo Álvares S/A, 1969.

SOARES, Magda. Português através de textos. $2^{\mathrm{a}}$ série. $2^{\mathrm{a}}$ edição. Belo Horizonte: Editora Bernardo Álvares S/A, 1967.

SOARES, Magda. Português através de textos. $3^{\mathrm{a}}$ série. $2^{\mathrm{a}}$ edição. Belo Horizonte: Editora Bernardo Álvares S/A, 1969.

SOUZA, Roberto Acízelo de. O império da eloquência: retórica e poética no Brasil oitocentista. Rio de Janeiro: EdUERJ, EdUFF, 1999.

SOUZA, Rosa Fátima de. História da organização do trabalbo escolar e do currículo no século XX: (ensino primário e secundário no Brasil). São Paulo: Cortez, 2008. 